\title{
Genetic Constitutions of Native Ducks in North Vietnam
}

\author{
Hisato Okabayashi ${ }^{1}$, Yuichi Tanabe ${ }^{1)}$, Yoshio Yamamoto ${ }^{2)}$, \\ Nguyen Thi $\mathrm{MiNH}^{3)}$ and Dang Vu BiN ${ }^{4)}$ \\ 1) School of Veterinary Medicine, Azabu University, Sagamihara 229-8501 \\ ${ }^{2)}$ Faculty of Applied Biological Science, Hiroshima University, \\ Higashi-Hiroshima 739-8528 \\ 3) Duck Breeding and Research Center, Dai Xuyen, Ha Tay, Vietnam \\ 4) Hanoi Agricultural University, Hanoi, Vietnam
}

\begin{abstract}
Genetic constitutions of the Co and the Bau, which were the Vietnamese native ducks, were investigated on the basis of the blood protein polymorphisms. Blood samples were collected in north Vietnam. Out of 22 loci controlling blood proteins, polymorphisms were observed at nine loci. From a dendrogram and a three-dimension scatter diagram on the first three principal components the Co and the Bau in north Vietnam were genetically similar to each other and the Co in north Vietnam was somewhat different from the Co in south Vietnam. However, these populations of Vietnamese native ducks seemed to be comparatively different from other Asian duck breeds.

Average heterozygosities $(\overline{\mathrm{H}})$ of the Co and the Bau in the North Vietnam were 0.105 and 0.113 , respectively.
\end{abstract}

(Jpn. Poult. Sci., $36: 245-254,1999)$

Key words : Vietnamese native ducks, genetic distance, genetic constitution, the Co, the $\mathrm{Bau}$

\section{Introduction}

A number of ducks are raised in southern area around the Mekong delta and northern area around Hanoi Province of Vietnam. The number is estimated to be about 44 millions and ranks as the second after China in the world. The number includes some exotic breeds of ducks such as the Pekin, the Khaki Campbell and the Cherry Valley in addition to native ducks. The exotic breeds including the Pekin grow faster and produce more eggs than the Vietnamese native ducks. The number of the exotic breed ducks is increasing in recent years. However, the Vietnamese native ducks will be sustained in the future because their numbers in Vietnam are great.

There are two breeds in Vietnamese native ducks, namely the Co and the Bau. The former is mainly distributed in the southern area around the Mekong delta and partly in the northern area around Hanoi Province, and the latter is distributed only in the northern area of Vietnam. In 1995, the blood protein polymorphisms of the Co ducks were investigated in the south Vietnam (OKABAYASH et al., $1998 \mathrm{a}, \mathrm{b}$ ). It was suggested that the Co was genetically distinct from the North East Asian duck breeds such as the Pekin, the White Tsaiya, the Kairyo Osaka, the Naki Ahiru and the Aokubi

Received December 22, 1998 Accepted March 23, 1999 
Ahiru, and also from the Indonesian native duck populations and the Khaki Campbell (see also Окавауналі et al., 1999). Biochemical genetic studies on the phylogeny of Asian duck breeds and population including Indonesian ducks breeds and populations were reported by TANABE (1994).

This study aims to elucidate the genetic constitutions of the native duck breeds of the Co and the Bau raised in north Vietnam based on the blood protein polymorphisms.

\section{Materials and Methods}

Seventy-three blood samples were collected from native ducks in north Vietnam. Of which 45 blood samples were collected from the Co and 28 from the Bau. Ten, ten and 25 of the Co's blood samples were collected at two farms in Hanoi and Bavi, Hanoi Province and a Duck Breeding and Research center in Phu Xuyen, Ha Tay Province, respectively. In the former two farms 50 to 100 of the Co were raised, and 200 of the Co were raised at the Duck Breeding and Reasearch Center. The Bau's blood samples were collected only at the Duck Breeding and Research Center, where more than 500 of the Bau were raised.

The blood was separated into plasma and erythrocyte fractions by centrifugation

Table 1. Gene frequencies of ten loci controlling the

\begin{tabular}{|c|c|c|c|c|c|c|}
\hline \multirow{2}{*}{\multicolumn{2}{|c|}{$\begin{array}{l}\text { Name of duck } \\
\text { No. Population }\end{array}$}} & \multirow{3}{*}{$\begin{array}{c}\begin{array}{c}\text { Number of } \\
\text { ducks }\end{array} \\
\mathbf{4 5}\end{array}$} & \multicolumn{2}{|c|}{$P a-1$} & \multicolumn{2}{|r|}{$\mathrm{Pa}-4$} \\
\hline & & & \multirow{2}{*}{$\frac{P a-1^{A}}{0.978}$} & \multirow{2}{*}{$\frac{P a-1^{B}}{0.022}$} & \multirow{2}{*}{$\frac{P a-4^{A}}{0.000}$} & \multirow{2}{*}{$\frac{P a-4^{B}}{1.000}$} \\
\hline 1 & Co (NV) & & & & & \\
\hline 2 & Bau (NV) & 28 & 0.929 & 0.071 & 0.000 & 1.000 \\
\hline 3 & Co (SV) & 214 & 0.523 & 0.477 & 0.023 & 0.886 \\
\hline 4 & Cirebon (I) & 96 & 0.734 & 0.266 & 0.015 & 0.985 \\
\hline 5 & Tangerang (I) & 101 & 0.624 & 0.376 & 0.038 & 0.962 \\
\hline 6 & Tasikmalaya (I) & 93 & 0.672 & 0.328 & 0.006 & 0.994 \\
\hline 7 & Tagel (I) & 91 & 0.676 & 0.324 & 0.000 & 1.000 \\
\hline 8 & Magelang (I) & 102 & 0.681 & 0.319 & 0.070 & 0.930 \\
\hline 9 & Mojosari (I) & 95 & 0.416 & 0.584 & 0.016 & 0.984 \\
\hline 10 & Mengwi (I) & 95 & 0.553 & 0.447 & 0.010 & 0.990 \\
\hline 11 & Bogor (I) & 33 & 0.682 & 0.318 & 0.000 & 1.000 \\
\hline 12 & Lombok & 99 & 0.591 & 0.409 & 0.000 & 1.000 \\
\hline 13 & Medan (I) & 30 & 0.550 & 0.450 & 0.000 & 1.000 \\
\hline 14 & Alabio (I) & 79 & 0.817 & 0.184 & 0.017 & 0.983 \\
\hline 15 & Khaki Campbell (E) & 69 & 0.544 & 0.457 & 0.000 & 1.000 \\
\hline 16 & Khaki Campbell (J) & 158 & 0.513 & 0.487 & 0.000 & 1.000 \\
\hline 17 & Pekin $(\mathrm{C})$ & 66 & 0.773 & 0.227 & 0.030 & 0.970 \\
\hline 18 & White Tsaiya $(\mathrm{T})$ & 50 & 0.610 & 0.390 & 0.040 & 0.960 \\
\hline 19 & Kairyo Osaka (J) & 103 & 0.718 & 0.282 & 0.000 & 1.000 \\
\hline 20 & Naki Ahiru (J) & 65 & 0.400 & 0.600 & 0.008 & 0.992 \\
\hline 21 & Aokubi Ahiru (J) & 71 & 0.563 & 0.437 & 0.028 & 0.972 \\
\hline 22 & Mallard $1(\mathrm{~J})$ & 51 & 0.578 & 0.422 & 0.000 & 1.000 \\
\hline 23 & Mallard $2(\mathrm{~J})$ & 43 & 0.698 & 0.302 & 0.000 & 1.000 \\
\hline
\end{tabular}

Abbreviations in parentheses mean the countries in which the ducks or mallards were raised I : Inodonesia, E : England, C : China, T : Taiwan, J : Japan, SV : Vietnam (Southern area), NV 
at $3000 \mathrm{rpm}$ for $10 \mathrm{~min}$. Both fractions were frozen at $-80^{\circ} \mathrm{C}$ in a laboratory at Faculty of Animal and Veterinary Science of Hanoi Agricultural University. The frozen blood samples were transported to the laboratory at Azabu University School of Veterinary Medicine. Twenty-two kinds of blood proteins were analyzed with horizontal starch gel electrophoresis and horizontal polyacrylamide gel electrophoresis. The detailed description of electrophoresis were given by TANABE (1994). Out of 22 proteins analyzed, nine proteins of plasma prealbumin-1 $(\mathrm{Pa}-1)$, plasma prealbumin-4 $(\mathrm{Pa}-4)$, plasma post transferrin-1 (Ptf-1), plasma leucine aminopeptidase-2 (Lap-2), erythrocyte phospho-hexose isomerase ( $P H I$ ), ery throcyte acid phosohatase-2 (AcP-2), erythrocyte estarase-1 (Es-1), erythrocyte esterase-3 (Es-3), and erythrocyte esterase-4 (Es-4) were polymorphic. The other proteins of plasma albumin $(A l b)$, plasma prealbumin2 ( $\mathrm{Pa}-2)$, plasma prealbumin-3 ( $\mathrm{Pa}-3)$, plasma prealbumin-5 ( $\mathrm{Pa}-5)$, plasma transferrin ( $T f$ ), plasma post transferrin-2 (Ptf-2), plasma leucine aminopeptidase-1 (LAP-1), erythrocyte acid phosphatase-1 $(A c p-1)$, erythrocyte esterase- $D_{1}\left(E s-D_{I}\right)$, erythrocyte lactate dehydrogenase-A $(L D H-A)$, ery throcyte lactate dehydrogenase-B $(L D H-B)$ and erythrocyte malate dehydrogenase $(M D H)$ were monomorphic. No polymorphisms of erythrocyte esterase- $\mathrm{D}_{2}\left(E s-D_{2}\right)$ were observed in the two duck breeds in north Viet-

blood protein polymorphisms in ducks

\begin{tabular}{|c|c|c|c|c|c|c|c|}
\hline \multirow[b]{2}{*}{$P a-4^{C}$} & \multicolumn{3}{|c|}{$\operatorname{Prf}-1$} & \multicolumn{3}{|c|}{$L A P-2$} & \multirow[b]{2}{*}{$E s-1^{A}$} \\
\hline & $P t f-1^{A}$ & $P t f-1^{B}$ & $P t f-1^{C}$ & $L A P-2^{A}$ & $L A P-2^{B}$ & $L A P-2^{\circ}$ & \\
\hline 0.000 & 0.033 & 0.967 & 0.000 & 0.506 & 0.000 & 0.494 & 0.900 \\
\hline 0.000 & 0.018 & 0.982 & 0.000 & 0.500 & 0.000 & 0.500 & 0.893 \\
\hline 0.091 & 0.101 & 0.848 & 0.051 & 0.785 & 0.096 & 0.120 & 0.639 \\
\hline 0.000 & 0.015 & 0.980 & 0.005 & 0.317 & 0.017 & 0.666 & 0.995 \\
\hline 0.000 & 0.014 & 0.986 & 0.000 & 0.602 & 0.027 & 0.371 & 0.995 \\
\hline 0.000 & 0.000 & 1.000 & 0.000 & 0.328 & 0.042 & 0.630 & 0.984 \\
\hline 0.000 & 0.008 & 0.992 & 0.000 & 0.428 & 0.021 & 0.551 & 1.000 \\
\hline 0.000 & 0.020 & 0.980 & 0.000 & 0.493 & 0.056 & 0.451 & 1.000 \\
\hline 0.000 & 0.015 & 0.980 & 0.005 & 0.305 & 0.100 & 0.595 & 0.988 \\
\hline 0.000 & 0.000 & 1.000 & 0.000 & 0.358 & 0.041 & 0.601 & 0.995 \\
\hline 0.000 & 0.109 & 0.891 & 0.000 & 0.457 & 0.061 & 0.483 & 1.000 \\
\hline 0.000 & 0.050 & 0.944 & 0.006 & 0.347 & 0.023 & 0.630 & 0.988 \\
\hline 0.000 & 0.032 & 0.952 & 0.016 & 0.408 & 0.067 & 0.525 & 0.983 \\
\hline 0.000 & 0.029 & 0.971 & 0.000 & 0.383 & 0.041 & 0.577 & 0.976 \\
\hline 0.000 & 0.035 & 0.930 & 0.035 & 0.455 & 0.057 & 0.488 & 0.977 \\
\hline 0.000 & 0.107 & 0.844 & 0.049 & 0.620 & 0.054 & 0.326 & 0.981 \\
\hline 0.000 & 0.103 & 0.857 & 0.040 & 0.675 & 0.047 & 0.277 & 0.983 \\
\hline 0.000 & 0.100 & 0.880 & 0.020 & 0.781 & 0.022 & 0.197 & 0.919 \\
\hline 0.000 & 0.290 & 0.710 & 0.000 & 0.646 & 0.071 & 0.283 & 0.976 \\
\hline 0.000 & 0.292 & 0.692 & 0.015 & 0.862 & 0.030 & 0.108 & 0.950 \\
\hline 0.000 & 0.120 & 0.873 & 0.007 & 0.803 & 0.040 & 0.157 & 0.986 \\
\hline 0.000 & 0.275 & 0.716 & 0.010 & 0.742 & 0.039 & 0.219 & 1.000 \\
\hline 0.000 & 0.548 & 0.452 & 0.000 & 0.451 & 0.112 & 0.437 & 1.000 \\
\hline
\end{tabular}

as follows.

: Vietnam (Northern area). 
nam. Polymorphisms of the enzyme were observed only in mallard 1 (migrating mallard, see TANABE, 1994). The symbols of the loci controlling the proteins were shown in the parentheses.

Genetic distances between the duck populations were calculated according to the method shown by NEI (1972). To elucidate the genetic relationship of the duck population, a dendrogram was drawn by UPG method of SNEATH and SoKAL (1973) and a three-dimension scatter diagram was drawn on the first three principal components calculated by variance-covariance matrix of allele frequencies. The heterogeneity of duck populations was estimated from the average heterozygosity $(\overline{\mathrm{H}})$ calculated from the average over 22 loci of heterozygosity per locus $\left(1-\mathrm{q}_{\mathrm{i}}{ }^{2}\right)$.

\section{Results}

Out of 22 protein loci analyzed, only nine were polymorphic. The frequencies of the alleles at the ten loci including $E s-D_{2}$ locus in the Co and the Bau ducks in the north Vietnam are given in Table 1. For comparison, the allele frequencies in the other duck breeds and mallard populations cited from Окаваунаян et al. (1998a) are also listed in Table 1. In the comparison between the Bau and the Co in the north Vietnam, the Bau

Table 1. (continued)

\begin{tabular}{|c|c|c|c|c|c|c|}
\hline \multirow{2}{*}{\multicolumn{2}{|c|}{$\begin{array}{l}\text { Name of duck } \\
\text { No. Population }\end{array}$}} & \multirow{3}{*}{$\begin{array}{c}\begin{array}{c}\text { Number of } \\
\text { ducks }\end{array} \\
\mathbf{4 5}\end{array}$} & \multirow{3}{*}{$\frac{E s-1}{E s-1^{B}}$} & \multicolumn{2}{|c|}{$E s-3$} & \multirow{3}{*}{$\frac{A c p-2^{A}}{0.067}$} \\
\hline & & & & \multirow{2}{*}{$\begin{array}{l}E s-3^{A} \\
\mathbf{0 . 4 4 4}\end{array}$} & \multirow{2}{*}{$\begin{array}{l}E s-3^{B} \\
0.556\end{array}$} & \\
\hline 1 & Co $(\mathbf{N V})$ & & & & & \\
\hline 2 & Bau (NV) & 28 & 0.107 & 0.500 & 0.500 & 0.161 \\
\hline 3 & Co $(\mathrm{SV})$ & 214 & 0.362 & 0.388 & 0.612 & 0.051 \\
\hline 4 & Cirebon (I) & 96 & 0.005 & 0.684 & 0.316 & 0.088 \\
\hline 5 & Tangerang (I) & 101 & 0.006 & 0.614 & 0.386 & 0.124 \\
\hline 6 & Tasikmalaya (I) & 93 & 0.017 & 0.629 & 0.371 & 0.346 \\
\hline 7 & Tagel (I) & 91 & 0.000 & 0.571 & 0.429 & 0.189 \\
\hline 8 & Magelang (I) & 102 & 0.000 & 0.665 & 0.335 & 0.017 \\
\hline 9 & Mojosari (I) & 95 & 0.013 & 0.505 & 0.495 & 0.051 \\
\hline 10 & Mengwi (I) & 95 & 0.005 & 0.380 & 0.620 & 0.301 \\
\hline 11 & Bogor (I) & 33 & 0.000 & 0.333 & 0.667 & 0.313 \\
\hline 12 & Lombok & 99 & 0.012 & 0.436 & 0.564 & 0.153 \\
\hline 13 & Medan (I) & 30 & 0.017 & 0.862 & 0.138 & 0.128 \\
\hline 14 & Alabio (I) & 79 & 0.024 & 0.428 & 0.572 & 0.075 \\
\hline 15 & Khaki Campbell (E) & 69 & 0.023 & 0.546 & 0.454 & 0.244 \\
\hline 16 & Khaki Campbell (J) & 158 & 0.019 & 0.613 & 0.387 & 0.181 \\
\hline 17 & Pekin $(\mathrm{C})$ & 66 & 0.017 & 0.605 & 0.395 & 0.354 \\
\hline 18 & White Tsaiya (T) & 50 & 0.081 & 0.380 & 0.620 & 0.224 \\
\hline 19 & Kairyo Osaka (J) & 103 & 0.025 & 0.418 & 0.583 & 0.264 \\
\hline 20 & Naki Ahiru (J) & 65 & 0.050 & 0.385 & 0.615 & 0.163 \\
\hline 21 & Aokubi Ahiru (J) & 71 & 0.015 & 0.319 & 0.681 & 0.194 \\
\hline 22 & Mallard $1(\mathrm{~J})$ & 51 & 0.000 & 0.628 & 0.373 & 0.059 \\
\hline 23 & Mallard $2(\mathrm{~J})$ & 43 & 0.000 & 0.390 & 0.611 & 0.138 \\
\hline
\end{tabular}


showed higher frequencies of $P a-1^{B}$ and $A c p-2^{A}$ than the Co, but other allele frequencies in the Bau were similar to those in the Co.

Significant differences of allele frequencies between the south Vietnam and the north Vietnam in the Co were found at $P a-1, L a p-2, E s-1$, and $E s-4$ loci. Higher frequencies of $P a-1^{B}$ and $E s-1^{B}$ than the Co in the north Vietnam were found in the Co in south Vietnam. $P a-4^{C}, P t f-1^{C}, L A P-2^{B}$ and $A c p-2^{o}$ were observed at lower frequencies in the Co in south Vietnam, while the alleles were not observed in the same breed in north Vietnam.

A dendrogram showing the genetic distance between duck populations is given in Figure 1, and a three dimension scatter diagram drawn from principal component scores of the population is given in Figure 2. The Co and the Bau in north Vietnam were located at near position to each other. Both populations also showed near relationship to the Co in south Vietnam, but remote relationship to the other Asian duck breeds.

Average heterozygosities $(\overline{\mathrm{H}})$ of the Vietnamese native and other Asian duck breeds including mallard populations are given in Table 2 . The estimates of average heterozygosity were ranged from 0.098 to 0.154 . The estimate $(0.105)$ of the Co in north

\begin{tabular}{|c|c|c|c|c|c|c|c|}
\hline \multicolumn{2}{|l|}{$A c p-2$} & \multicolumn{2}{|c|}{$P H I$} & \multicolumn{2}{|c|}{$E s-4$} & \multicolumn{2}{|c|}{$E s-D_{2}$} \\
\hline$A c p-2^{B}$ & $A c p-2^{o}$ & $P H I^{A}$ & $P H I^{B}$ & $E s-4^{A}$ & $E s-4^{B}$ & $E S-D_{2}{ }^{A}$ & $E S-D_{2}{ }^{B}$ \\
\hline 0.933 & 0.000 & 0.711 & 0.289 & 0.444 & 0.556 & 0.000 & 1.000 \\
\hline 0.839 & 0.000 & 0.714 & 0.286 & 0.446 & 0.554 & 0.000 & 1.000 \\
\hline 0.926 & 0.023 & 0.670 & 0.330 & 0.560 & 0.441 & 0.000 & 1.000 \\
\hline 0.734 & 0.179 & 0.783 & 0.217 & 0.843 & 0.157 & 0.000 & 1.000 \\
\hline 0.637 & 0.239 & 0.750 & 0.250 & 0.843 & 0.157 & 0.000 & 1.000 \\
\hline 0.521 & 0.133 & 0.740 & 0.260 & 0.837 & 0.163 & 0.000 & 1.000 \\
\hline 0.612 & 0.199 & 0.853 & 0.147 & 0.791 & 0.209 & 0.000 & 1.000 \\
\hline 0.824 & 0.159 & 0.811 & 0.189 & 0.817 & 0.183 & 0.000 & 1.000 \\
\hline 0.588 & 0.361 & 0.515 & 0.485 & 0.796 & 0.204 & 0.000 & 1.000 \\
\hline 0.538 & 0.160 & 0.455 & 0.545 & 0.643 & 0.357 & 0.000 & 1.000 \\
\hline 0.473 & 0.214 & 0.618 & 0.382 & 0.462 & 0.539 & 0.000 & 1.000 \\
\hline 0.602 & 0.245 & 0.625 & 0.375 & 0.753 & 0.247 & 0.000 & 1.000 \\
\hline 0.540 & 0.333 & 0.650 & 0.350 & 0.450 & 0.550 & 0.000 & 1.000 \\
\hline 0.676 & 0.250 & 0.962 & 0.038 & 0.597 & 0.403 & 0.000 & 1.000 \\
\hline 0.498 & 0.258 & 0.900 & 0.100 & 0.464 & 0.536 & 0.000 & 1.000 \\
\hline 0.448 & 0.371 & 0.607 & 0.393 & 0.504 & 0.496 & 0.000 & 1.000 \\
\hline 0.314 & 0.333 & 0.443 & 0.557 & 0.474 & 0.526 & 0.000 & 1.000 \\
\hline 0.588 & 0.192 & 0.082 & 0.918 & 0.417 & 0.583 & 0.000 & 1.000 \\
\hline 0.378 & 0.358 & 0.208 & 0.793 & 0.568 & 0.432 & 0.000 & 1.000 \\
\hline 0.552 & 0.286 & 0.482 & 0.518 & 0.361 & 0.640 & 0.000 & 1.000 \\
\hline 0.534 & 0.272 & 0.223 & 0.777 & 0.381 & 0.619 & 0.000 & 1.000 \\
\hline 0.734 & 0.268 & 0.069 & 0.931 & 0.469 & 0.531 & 0.020 & 0.980 \\
\hline 0.415 & 0.447 & 0.456 & 0.544 & 0.379 & 0.621 & 0.000 & 1.000 \\
\hline
\end{tabular}




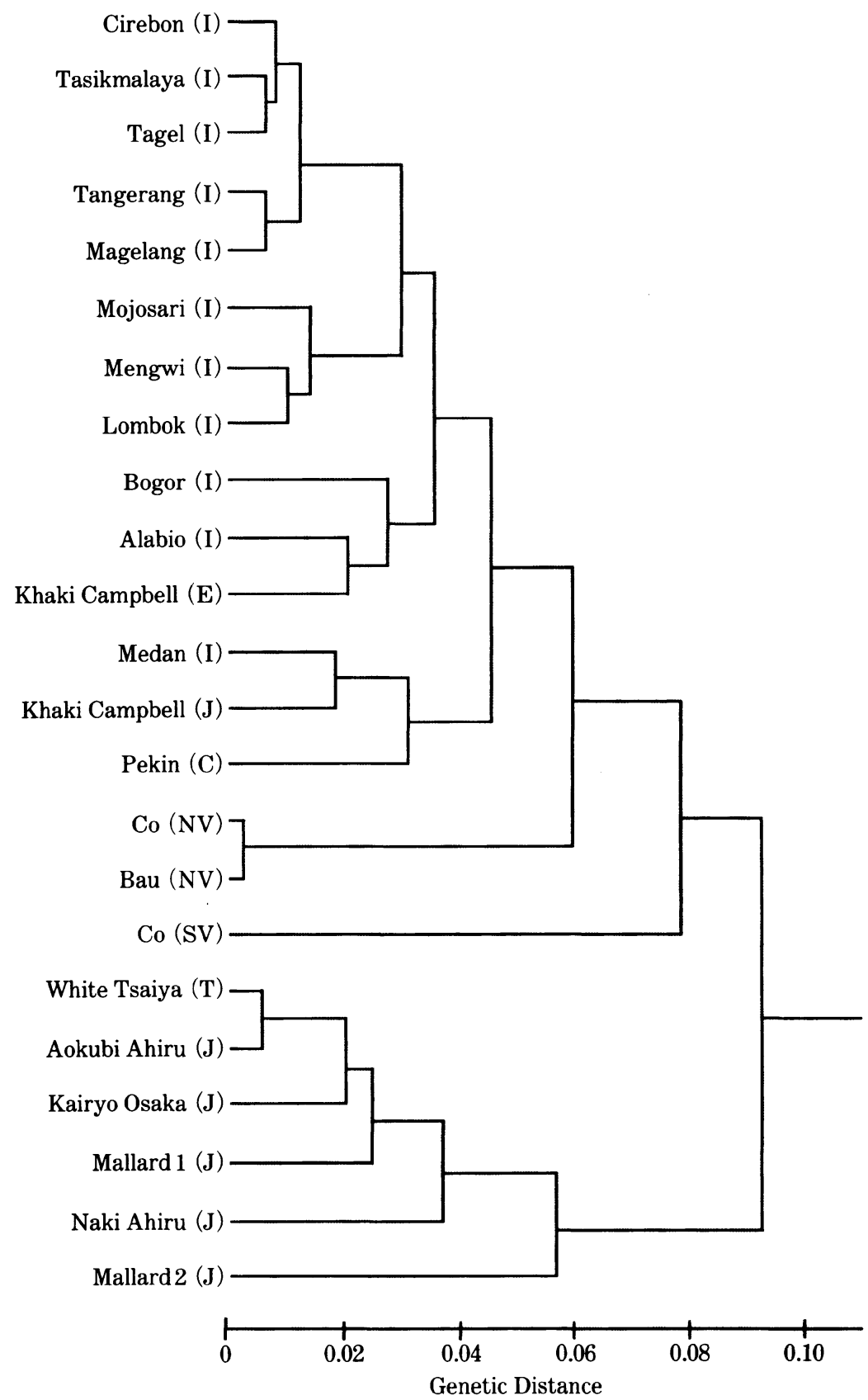

Fig. 1. A dendrogram drawn by UPG method based on Nei's genetic distance between duck populations.

Vietnam was lower than that $(0.152)$ of the Co in south Vietnam, which was at the least level among the populations investigated until now. The value (0.113) of the Bau was also low. 


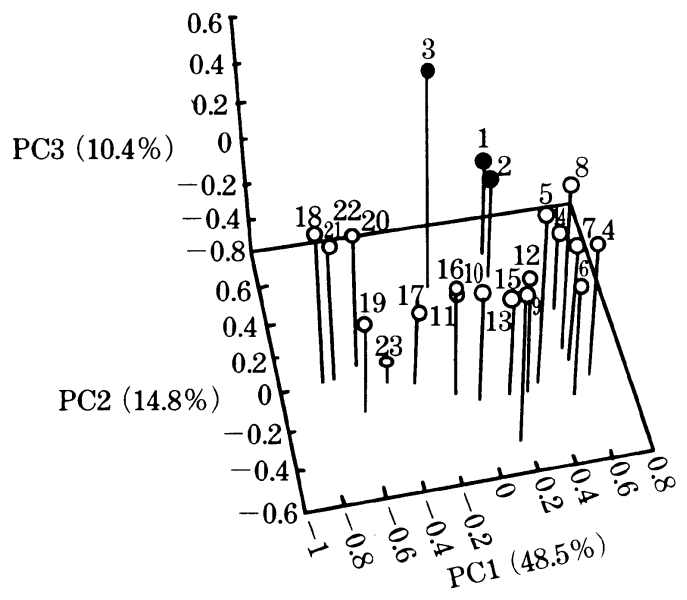

\begin{aligned} \hline \hline No. & \multicolumn{1}{c}{ Population } \\ \hline 1 & Co (NV) \\ 2 & Bau (NV) \\ 3 & Co (NV) \\ 4 & Cirebon (I) \\ 5 & Tangerang (I) \\ 6 & Tasikmalaya (I) \\ 7 & Tagel (I) \\ 8 & Magelang (I) \\ 9 & Mojosari (I) \\ 10 & Mengwi (I) \\ 11 & Bogor (I) \\ 12 & Lombok (I) \\ 13 & Medan (I) \\ 14 & Alabio (I) \\ 15 & Khaki Campbell (E) \\ 16 & Khaki Campbell (J) \\ 17 & Pekin (C) \\ 18 & White Tsaiya (T) \\ 19 & Kairyo Osaka (J) \\ 20 & Naki Ahiru (J) \\ 21 & Aokubi Ahiru (J) \\ 22 & Mallard 1 (J) \\ 23 & Mallard 2 (J) \\ & \end{aligned}

Fig. 2. A three dimension scatter diagram drawn based on the first three principal components.

\section{Discussion}

According to DANG (1998)'s review, the Co and the Bau may differ somewhat each other in mature body weight and adult plumage color. In recent years, exotic duck breeds such as the Pekin, the Cherry Valley and the Khaki Campbell have been introduced into Vietnam.

Scientific reports on the Co could not been available until the genetic investigation on the Co in south Vietnam was started in 1995. Genetic constitutions of the Co in south Vietnam and its phylogenetic relationships with other Asian ducks were reported by Окавауналі et al., (1998ab). Recently, genetic constitutions of Japanese native ducks were also investigated by OKавау ASH $e t$ al., (1999). They suggested that genetic constitutions of the Co differed from those of the North-east Asian duck populations consisting of the Pekin, the Naki Ahiru, the Aokubi Ahiru, the Kairyo Osaka and the White Tsaiya, and is distinct from those of the Indonesian native ducks and the Khaki Campbell. The present study with our previous study (OKABAYASH $e t$ al., 1998a) show that the genetic positions of the three populations in north and south Vietnam locate between the duck breeds in northeast Asia and those in Southeast Asia including of Indonesian ducks and the Khaki Campbell.

However, in the present study genetic constitutions of the Co in north Vietnam were somew hat different from the Co in south Vietnam. Vietnam is narrow from east to west and very long beyond $1100 \mathrm{~km}$ from north to south. Central area of Vietnam 
Jpn. Poult. Sci., 36 (4)

Table 2. Average heterozygosities of the duck populations

\begin{tabular}{|c|c|c|c|}
\hline \multicolumn{2}{|c|}{$\begin{array}{l}\text { Name of duck } \\
\text { No. populations }\end{array}$} & \multirow{2}{*}{$\begin{array}{c}\begin{array}{c}\text { Number of } \\
\text { ducks }\end{array} \\
\mathbf{4 5}\end{array}$} & \multirow{2}{*}{$\begin{array}{c}\begin{array}{c}\text { Average } \\
\text { heterozygosity }\end{array} \\
\mathbf{0 . 1 0 5}\end{array}$} \\
\hline 1 & Co (NV) & & \\
\hline 2 & Bau (NV) & 28 & 0.113 \\
\hline 3 & Co (SV) & 214 & 0.152 \\
\hline 4 & Cirebon (I) & 96 & 0.125 \\
\hline 5 & Tangerang (I) & 101 & 0.123 \\
\hline 6 & Tasikmalaya (I) & 93 & 0.127 \\
\hline 7 & Tagel (I) & 91 & 0.118 \\
\hline 8 & Magelang (I) & 102 & 0.136 \\
\hline 9 & Mojosari (I) & 95 & 0.135 \\
\hline 10 & Mengwi (I) & 95 & 0.139 \\
\hline 11 & Bogor (I) & 33 & 0.147 \\
\hline 12 & Lombok & 99 & 0.114 \\
\hline 13 & Medan (I) & 30 & 0.151 \\
\hline 14 & Alabio (I) & 79 & 0.098 \\
\hline 15 & Khaki Campbell (E) & 69 & 0.137 \\
\hline 16 & Khaki Campbell (J) & 158 & 0.154 \\
\hline 17 & Pekin $(\mathrm{C})$ & 66 & 0.149 \\
\hline 18 & White Tsaiya (T) & 50 & 0.144 \\
\hline 19 & Kairyo Osaka (J) & 103 & 0.151 \\
\hline 20 & Naki Ahiru (J) & 65 & 0.150 \\
\hline 21 & Aokubi Ahiru (J) & 71 & 0.136 \\
\hline 22 & Mallard $1(\mathrm{~J})$ & 51 & 0.128 \\
\hline 23 & Mallard $2(\mathrm{~J})$ & 43 & 0.179 \\
\hline
\end{tabular}

Average heterozygosity was estimated from average of heterozygosity in each locus over twenty two loci.

is especially narrow from east to west, and mostly dry and arid mountainous land, where is not suitable to keep ducks, because ducks can live only in wet waterful areas. Most of ducks in Vietnam are raised in northern plain area around Hanoi Province and southern plain area around the Mekong delta. As the distance between the northern and the southern areas is too long for the migration of the population, genetic exchange of the Co ducks between northern and southern area seems to be little. Further, it was possible that the Co had crossed with the Bau in north Vietnam. In this study, the Co and the Bau in north Vietnam were found to be rather similar genetic constitutions. The Bau originates in Cho Ben, Hoa Binh Province, Vietnam, and might be genetically differ from the Co due to DANG (1998). The Co has a smaller body size and produces less eggs than the Bau. It was possible to cross the Bau to the Co to improve growth rate and egg production. However, the body sizes of both the duck breeds apparently so differed to each other that the crossbreeding might not be possible in the populations of the Co and the Bau ducks in north Vietnam at least in recent years. The present study suggests the presence of considerably high genetic random drifts among the duck populations in north and south Vietnam, because a 
close genetic relation was observed between the Co and the Bau in north Vietnamin than between the Co in north Vietnam and that in south Vietnam. It should be note worthy that the duck breeds of Vietnam had not been pedigree-bred, and they can be called populations instead of breed although their external features are similar.

The average heterozygosities of ducks and mallards were ranged from 0.098 to 0.179 , and the values were at same levels compared with those in Asian native horse and dog populations but at higher level than those of water buffalo and Asian native goat populations (NozAwA, 1994). In poultry similar estimates of 0.078 to 0.162 in Indonesian, Lanka, Fijian and Bangladesh native chickens (MAEDA et al., 1987) were reported. A range from 0.098 to 0.179 of the average heterozygosities of ducks and mallards estimated in the study is considered to be at a medium level of the estimate. Lower estimates of $\overline{\mathrm{H}}$ in the Co in north Vietnam might be caused by small size breeding systems. However, the same reason might not be true in the Bau, since the local population size of the Bau from which blood samples were collected was exceptionally large as more than 500 in north Vietnam. The other reasons for the low estimate in the Bau may be considered as a bottle-neck effect or sampling error. Comparatively large estimate of the Co in south Vietnam might be caused by larger population size breeding system. Average heterozygosity varies due to population size and reproduction systems of the population. More informations on actual numbers of male and female in mating and breeding history of the populations will be necessary in the field studies.

\section{Acknowledgement}

We thank Miss Tomoko Hayashida for her technical assistance. The study was financially supported by a Grant-in-Aid for International Scientific Research (Field Research) from the Japanese Ministry of Education, Science, Sports and Culture, No. 08041151.

\section{References}

DANG V. B. (1998) Some main characteristics of native domestic animal breeds in Vietnam. Rec. Soc. Res. Native Livestock $16: 1-12$.

MAEDA, Y., OKADA I., HaSnath M,A, MAJid M.A. and Islam M.N. (1987) Blood protein polymorphisms of native fowl and red jungle fowl in Bangladesh. Genetic studies on breed differentiation of the native domestic animals in Bangladesh. $2: 27-45$.

NeI, M. (1972) Genetic distance between populations. Amer. Nat., 106 : 283-292.

Nozawa, K. (1994) Animal population genetics. P. 210 Nagoya University Press, Nagoya. (in Japanese)

Okabayashi, H., Yokoyama H., Tanabe Y., Namikawa T., Yamagata T., Yamamoto Y., Amano T., Tsunoda K., Chau B. L., and Vo-Tong X. (1998a) Phylogenetic studies of the Vietnamese native ducks, one of the Asian duck populations based on the blood protein polymorphisms. Animal Science and Technology 69 : 713-719.

Okabayashi, H., Yokoyama H., Tanabe Y., Namikawa T., Yamamoto Y., Amano T., Tsunoda K.., Yamagata T., Chau B. L., and Vo-Tong X. (1998b) Blood protein polymorphisms of the southern Vietnamese native ducks and its phylogenetic relationships with other Asian native ducks. Rep. Soc. Native Livestock $16: 137-148$. (in Japanese)

OKabayashi, H., Yokoyama H., Tanabe Y. (1999) Gene Constitutions of the Japanese native ducks 
of the Naki Ahiru (Puddle Duck) and the Aokubi Ahiru (Japanese Mallard Duck) and their phylogenetic relationships among the Asian native ducks. Japanese Poultry Science 36 : 116122 (in Japanese)

Sneath, P.H.A. and Sokal R.R. (1973) Numerical taxonomy. pp. 230-234. Freeman. San Francisco TANABE Y. (1994) Biochemical-genetic studies on phylogeny of the duck breeds. In : (MARKERT, C. L., Scandalios, J.G., Lim, H.A. and Serov, O.L. eds.) Isozymes : Organization and roles in evolution, Genetic and physiology, World Scientific, Sigapore. pp. 297-308.

\title{
ベトナム北部における在来アヒルの遺伝子構成
}

\author{
岡林寿人 ${ }^{1)} \cdot$ 田名部雄一1) $・$ 山本義雄 $^{2)}$ \\ Nguyen Thi MiNH ${ }^{3)} \cdot$ Dang Vu BiN ${ }^{4)}$ \\ 1) 麻布大学獣医学部, 相模原市 229-8501 \\ 2) 広島大学生物生産学部, 東広島市 739-8528 \\ ${ }^{3)}$ Duck Breeding and Research Center, Dai Xuyen, Ha Tay, Vietnam \\ 4) Hanoi Agricultural University, Hanoi, Vietnam
}

ベトナムのハノイ市を中心とした北部地域において飼 養されている在来アヒル Co と Bau について 22 種類の 血液タンパク質の遺伝的変異を調べた。また, ベトナム 在来アヒルをはじめ他のアジア産アヒルにおいても平均 ヘテロ接合体率を推定した。ベトナム北部の在来アヒル において多型を示したのは 22 タンパク質のうち 9 種類 (座位) であった。マガモのみに多型の見出されている $E s-D_{2}$ を含めた 10 座位における遺伝子の頻度を基に調 査した集団の間で Nei の遺伝的距離を求め，それに基づ いて枝分かれ図を描いた。また, 遺伝子頻度の分散共分 散行列に基づく行列から主成分分析を行い, その第一〜 三成分を基にして三次元の散布刅を描いた。べトナム北
部におけるCo と Bau の遺伝子構成は全体的によく似 通っていた。また, 北部の Co と南部の Co とはその遺伝 子構成がやや異なっていた。枝分かれ図ならびに散布図 から, 北部の Co と Bau とは互いに比較的近い位置にあ り，またベトナム南部の Co とはすこし離れていたが, これらの 3 集団はともに東北アジア産アヒルともインド ネシア産アヒルとも少し離れたところに位置することが 分かった。ベトナム北部の Co と Bauの $\overline{\mathrm{H}}$ はそれぞれ 0.105 および 0.113 であった。

(家禽会誌, $36: 245-254,1999)$ キーワード：ベトナム在来アヒル, 血液タンパク質多 型, 遺伝的距離, 遺伝子構成 